\title{
Study on Mitigation Method of Solder Corrosion for Crystalline Silicon Photovoltaic Modules
}

\author{
Ju-Hee Kim, ${ }^{1}$ Jongsung Park, ${ }^{2}$ Donghwan Kim, ${ }^{3}$ and Nochang Park ${ }^{1}$ \\ ${ }^{1}$ Components \& Materials Physics Research Center, Korea Electronic Technology Institute, No. 68, Yaptap-dong, Bundang-gu, \\ Seongnam-si, Gyeonggi-do 463-816, Republic of Korea \\ ${ }^{2}$ School of Photovoltaic and Renewable Energy Engineering, University of New South Wales, Sydney, NSW 2052, Australia \\ ${ }^{3}$ Department of Materials Science and Engineering, Korea University, Anam-dong, Seongbuk-gu, Seoul 136-701, Republic of Korea
}

Correspondence should be addressed to Nochang Park; ncpark@keti.re.kr

Received 31 July 2014; Revised 16 October 2014; Accepted 9 December 2014; Published 22 December 2014

Academic Editor: Ahmad Umar

Copyright (C) 2014 Ju-Hee Kim et al. This is an open access article distributed under the Creative Commons Attribution License, which permits unrestricted use, distribution, and reproduction in any medium, provided the original work is properly cited.

\begin{abstract}
The corrosion of $62 \mathrm{Sn} 36 \mathrm{~Pb} 2 \mathrm{Ag}$ solder connections poses serious difficulties for outdoor-exposed photovoltaic (PV) modules, as connection degradation contributes to the increase in series resistance $\left(R_{S}\right)$ of PV modules. In this study, we investigated a corrosion mitigation method based on the corrosion mechanism. The effect of added sacrificial metal on the reliability of PV modules was evaluated using the oxidation-reduction (redox) reaction under damp heat (DH) conditions. Experimental results after exposure to $\mathrm{DH}$ show that the main reason for the decrease in power was a drop in the module's fill factor. This drop was attributed to the increase of $R_{S}$. The drop in output power of the PV module without added sacrificial metal is greater than that of the sample with sacrificial metal. Electroluminescence and current-voltage mapping analysis also show that the PV module with sacrificial metal experienced less degradation than the sample without sacrificial metal.
\end{abstract}

\section{Introduction}

Photovoltaic (PV) energy holds an important position in the renewable energy market. Solar energy collected by PV modules is used for industrial, communal, and individual needs. Over the past decade, the PV market has experienced unprecedented growth. In the past year, solar power has reached a cumulative installed capacity of roughly $130 \mathrm{GW}$ worldwide [1]. Stable power generation over time is of vital importance to the growth of the PV industry. A low power decline over time, or degradation rate $\left(R_{D}\right)$, is essential to all stakeholders-utility companies, integrators, investors, and researchers alike. Financially, limiting the degradation of a PV module or system is equally important because a higher $R_{D}$ translates directly into less power produced, which reduces future cash flow [2]. In order to decrease the $R_{D}$ of a PV module, it is important to understand the degradation mechanisms within the module because any of them may eventually lead to the failure of the whole module. Information regarding the degradation of PV modules has been available since the early 1970s [3]. Degradation mechanisms are classified into the two groups: early degradation and longterm degradation. In recent research, degradation problems in field-aged PV modules $[4,5]$ have been detected in plants operating for short periods of time [6] due to changes in the design of PV modules, as the PV industry works to decrease production costs for solar cells and panels. Early degradations include discoloration and delamination of encapsulant materials [7, 8], bubble formation in the back sheet [7], cell cracks [9], burnt cells caused by hot spots [7], and defects in the antireflective coatings [7]. These degradations are also found in long-term field-aged PV modules. In addition, the corrosion of solder joints $[10,11]$ and cracks in solder joints [12] have occurred in long-term operating PV modules. Of these degradation modes, the occurrence of corrosion has one of the highest frequencies in outdoor-exposed PV modules [10, 11, 13-17]. Corrosion of various PV components has been found to increase the series resistance $\left(R_{S}\right)$ of $\mathrm{PV}$ modules [18]. Significant losses in PV module performance 


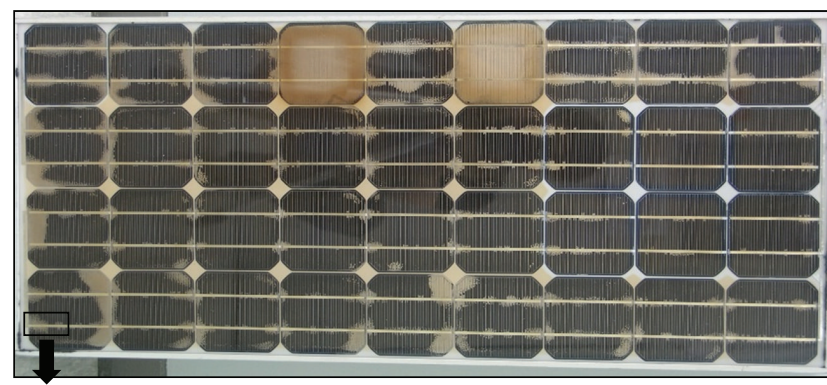

(a)

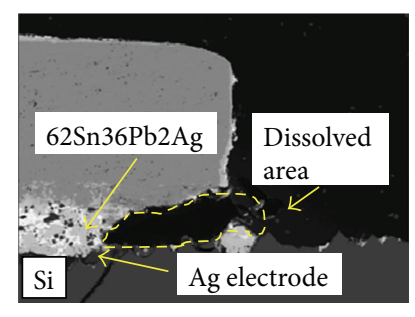

(b)

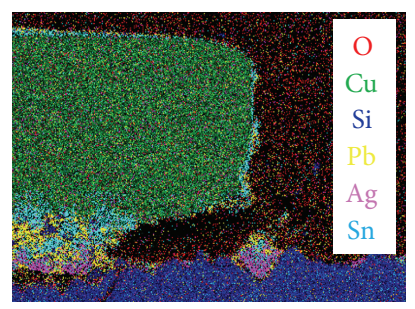

(c)

FIGURE 1: Cross-sectional SEM micrographs: (a) 25-year-aged PV module, (b) cross-sectional image at the solder interconnection, and (c) energy-dispersive X-ray (EDX) mapping image.

are due to the corrosion of the cell, that is, the degradation of the SiNx antireflection coating, or the corrosion of metallic materials, such as cracks in solder bonds and the formation of Ag fingers [16, 17]. Corrosion is defined as the destructive chemical or electrochemical reaction of a metal with its environment. Moisture from the environment may lead to electrochemical reactions that can result in corrosion, as the aqueous ion-conducting atmosphere enables the reactivity of metals in PV modules [19].

Traditionally, the individual solar cells in a crystalline silicon PV module are connected in series using flattened copper $(\mathrm{Cu})$ wires, which are dipped in molten solder material. The $\mathrm{Cu}$ wire is soldered to the silver (Ag) electrode on the face of the cell. $62 \mathrm{Sn} 36 \mathrm{~Pb} 2 \mathrm{Ag}$ solder is widely used owing to its good solderability with Ag, low melting temperature, and satisfactory mechanical properties. However, tin (Sn) and lead $(\mathrm{Pb})$ both dissolve in the presence of atmospheric water because of galvanic corrosion [20]. In order to understand the effects of galvanic corrosion on the degradation of PV modules, we must comprehend the galvanic corrosion mechanism. Therefore, in this study, the corrosion of $62 \mathrm{Sn} 36 \mathrm{~Pb} 2 \mathrm{Ag}$ solder interconnections was inspected in a 25-year-aged PV module. Based on the observed mechanism of galvanic corrosion, a mitigation method was developed. The effect of this mitigation method on the long-term reliability of PV modules was evaluated under damp heat $(\mathrm{DH})$ conditions.

\section{Corrosion Mechanism of Solder Interconnections}

Cross-sectional analysis was performed on a 25-year-aged crystalline silicon PV module. The information regarding this PV module was reported in previous research [21]. The results of the analysis revealed that both $\mathrm{Sn}$ and $\mathrm{Pb}$ can undergo severe corrosion in PV modules over time, as shown in Figure 1. The SEM micrograph implies that the $\mathrm{Sn}$ and $\mathrm{Pb}$ in the solder material dissolved in moisture as a result of galvanic corrosion $[11,22]$. In the fabrication of typical PV modules, $\mathrm{Cu}$ wire is plated with $62 \mathrm{Sn} 36 \mathrm{~Pb} 2 \mathrm{Ag}$ solder, generating six galvanic couples: $\mathrm{Ag}-\mathrm{Pb}, \mathrm{Ag}-\mathrm{Sn}, \mathrm{Cu}-$ $\mathrm{Pb}, \mathrm{Cu}-\mathrm{Sn}, \mathrm{Ag}-\mathrm{Cu}$, and $\mathrm{Sn}-\mathrm{Pb}$. The oxidation potentials of $\mathrm{Ag} / \mathrm{Ag}(\mathrm{I}), \mathrm{Cu} / \mathrm{Cu}(\mathrm{II}), \mathrm{Pb} / \mathrm{Pb}(\mathrm{II})$, and $\mathrm{Sn} / \mathrm{Sn}(\mathrm{II})$ are +0.799 ,
$+0.337,-0.126$, and $-0.136 \mathrm{~V}$, respectively. The metals with lower potential values, referred to as sacrificial metals, will generally corrode at greater rates than the metals with higher potential values. Accordingly, $\mathrm{Sn}$ and $\mathrm{Pb}$ materials become the anode and tend to corrode at an accelerated rate, whereas $\mathrm{Ag}$ and $\mathrm{Cu}$ materials act as the cathode in the so-called corrosion cell. The anode and cathode reactions are indicated in (1) and (2), respectively:

$$
\begin{gathered}
2 \mathrm{Sn} \longrightarrow 2 \mathrm{Sn}^{2+}+4 e \\
2 \mathrm{Sn}^{2+}+4 \mathrm{OH}^{-} \longrightarrow 2 \mathrm{Sn}(\mathrm{OH})_{2} \\
2 \mathrm{~Pb}^{2+}+4 \mathrm{OH}^{-} \longrightarrow 2 \mathrm{~Pb}(\mathrm{OH})_{2} \\
\mathrm{O}_{2}+4 e+2 \mathrm{H}_{2} \mathrm{O} \longrightarrow 4 \mathrm{OH}^{-}
\end{gathered}
$$

Oxidation and reduction occur in the anode and cathode, respectively. Figure 2 illustrates the corrosion mechanism at the interface between $\mathrm{SnPb}$ solder plated ribbon and $\mathrm{Ag}$.

The micrograph results suggest that the corrosion of solder interconnections resulted from different oxidation potential values between the component metals.

Therefore, a metal with a lower potential value than both $\mathrm{Sn}$ and $\mathrm{Pb}$, when added to the corrosion cell system, will act as the anode and tend to corrode. The oxidation potential values for $\mathrm{Zn} / \mathrm{Zn}$ (II) and $\mathrm{Al} / \mathrm{Al}$ (III) are $-0.763 \mathrm{~V}$ and $-1.662 \mathrm{~V}$, respectively. $\mathrm{Zn}$ and $\mathrm{Al}$ both corrode at a greater rate than $\mathrm{Sn}$ and $\mathrm{Pb}$ when added to the $\mathrm{PV}$ solder system, as shown in Figure 3.

\section{Experiments}

3.1. Sample Fabrication. In this study, two types of PV modules were prepared to evaluate the effect of a sacrificial anode. First, $156 \mathrm{~mm} \times 156 \mathrm{~mm}$ multicrystalline silicon (Si) solar cells with two bus bars were used and interconnected by $\mathrm{Cu}$ wire plated with $62 \mathrm{Sn} 36 \mathrm{~Pb} 2 \mathrm{Ag}$ solder. In order to accelerate the corrosion process, these modules were not laminated, as shown in Figure 4. One group had $\mathrm{Zn}$ metal soldered to the $\mathrm{Cu}$ wire as a sacrificial metal (Figure 4(b)). The other group had no added $\mathrm{Zn}$ metal (Figure 4(a)). Fifteen cells were prepared for testing in each condition. 


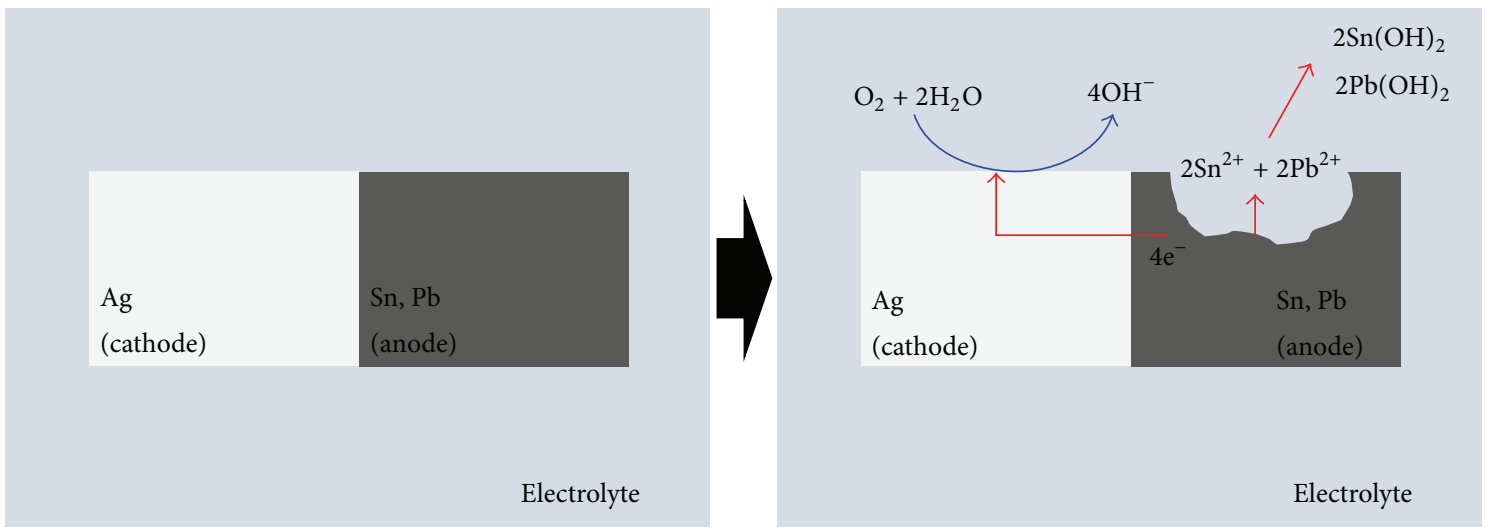

FIGURE 2: Corrosion mechanism at the interface between $\mathrm{SnPb}$ solder and $\mathrm{Ag}$ paste.

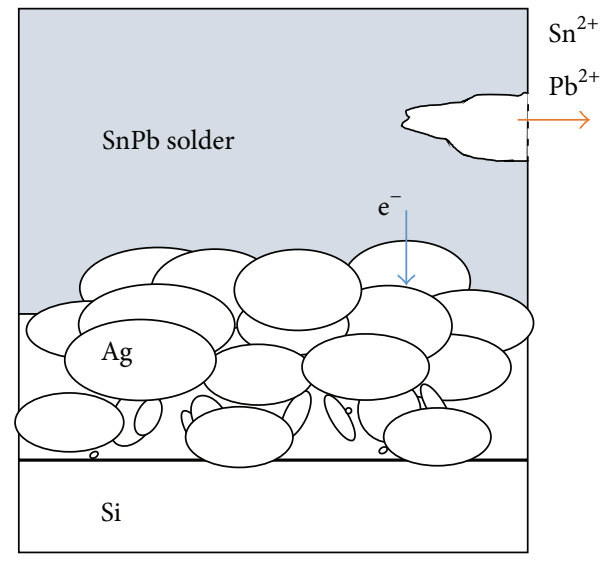

(a)

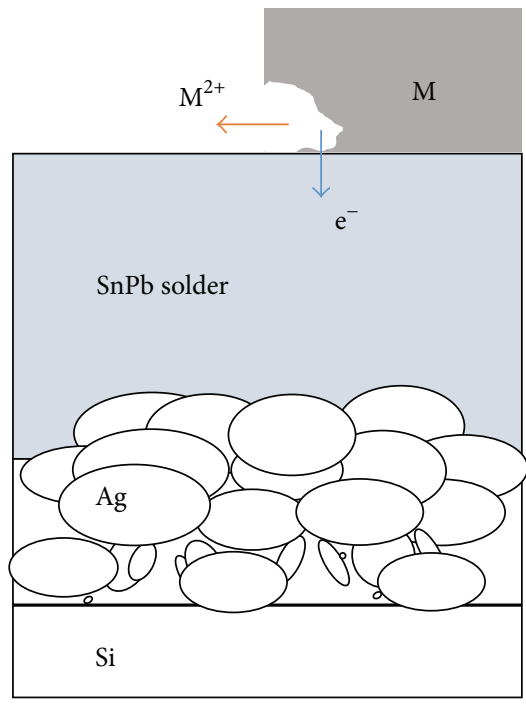

(b)

Figure 3: A mitigation method for corrosion of SnPb solder: (a) corrosion of the sample without sacrifice metal and (b) corrosion of the sample with a sacrificial metal anode ( $\mathrm{Zn}$ or $\mathrm{Al})$.

Next, $156 \mathrm{~mm} \times 156 \mathrm{~mm}$ monocrystalline Si solar cells with three bus bars were used. The modules were composed of four cells, laminated with a $360 \mathrm{~mm} \times 360 \mathrm{~mm}$ low-iron glass and EVA sheet, with Tedlar/PET/Tedlar (TPT) back-sheet, as shown in Figure 5. One group of this second set of samples used $\mathrm{Al}$ as a sacrificial metal (Figure 5(b)), while the other was left as-constructed. Al was used as a sacrificial metal because it possesses a lower oxidation potential than $\mathrm{Zn}$. The mass of $\mathrm{Al}$ attached to each sample was $0.15 \pm 0.01 \mathrm{~g}$.

3.2. Stress Profile. The samples were exposed to damp heat (DH) conditions of $85^{\circ} \mathrm{C}$ and $85 \%$ relative humidity, based on the IEC 61215 standard, for $3000 \mathrm{~h}$. Before measurements, the samples were stored for $6 \mathrm{~h}$ at room temperature.

3.3. Characterization. The electrical properties of the PV modules were measured every $500 \mathrm{~h}$ using a solar simulation system (K202-Lab200, Mac Science, Seoul, South Korea). The standard test conditions were (a) irradiance: $1000 \mathrm{~W} / \mathrm{m}^{2}$, (b) cell temperature: $25^{\circ} \mathrm{C}$, and (c) spectral distribution of irradiance: AM 1.5G (IEC 60904-3). Current and voltage (I$V)$ mapping characteristics of the PV modules were measured by a solar cell conversion efficiency distribution measurement system (MP150, Lasertec Co., Yokohama, Japan). Electroluminescence (EL, Zyla, Andor Technology Co., Belfast, UK) was used to detect the degradation of the PV modules.

\section{Results and Discussion}

4.1. Effect of Zn Metal on the Electrical Parameters. Figure 6 shows that $\mathrm{Zn}$ metal corroded with increasing test time. The added $\mathrm{Zn}$ metal corrodes away after $1000 \mathrm{~h}$ under DH conditions (Figure 6(d)). This indicates that the sacrificial anode corroded instead of $\mathrm{Sn}$ and $\mathrm{Pb}$. To evaluate the effect of the $\mathrm{Zn}$ 
TABLE 1: Changes in normalized electrical parameters of PV cells with and without $\mathrm{Zn}$ after $3000 \mathrm{~h}$.

\begin{tabular}{lccccc}
\hline Sample & Pm $(\%)$ & $V_{\mathrm{OC}}(\%)$ & $I_{\mathrm{SC}}(\%)$ & FF $(\%)$ & $R_{S}(\%)$ \\
\hline W/O Zn & -86.3 & -6.2 & -62.9 & -60.7 & 1190 \\
W/Zn & -31.1 & -4.7 & -0.7 & -30.2 & 220 \\
\hline
\end{tabular}

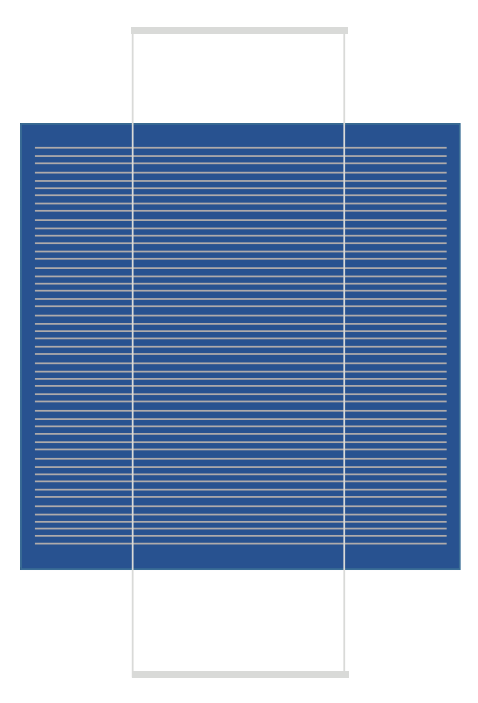

(a)

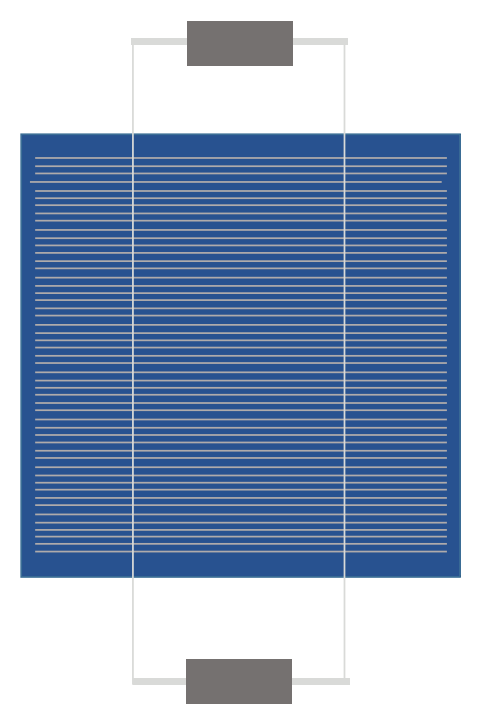

(b)

FIGURE 4: Schematic of the PV cell: (a) front side of the sample without Zn and (b) front side of the sample with Zn.

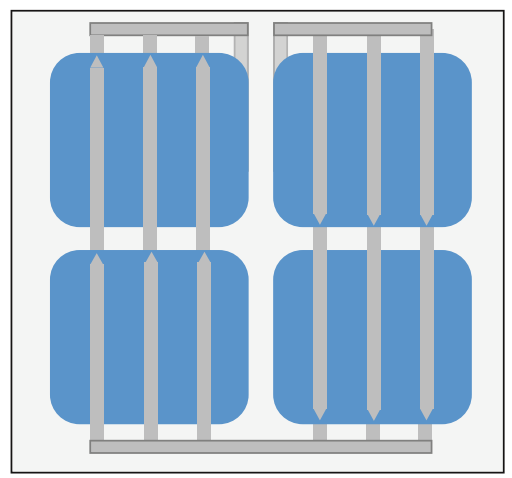

(a)

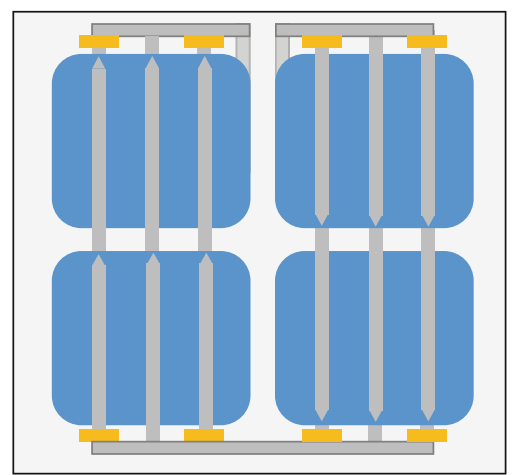

(b)

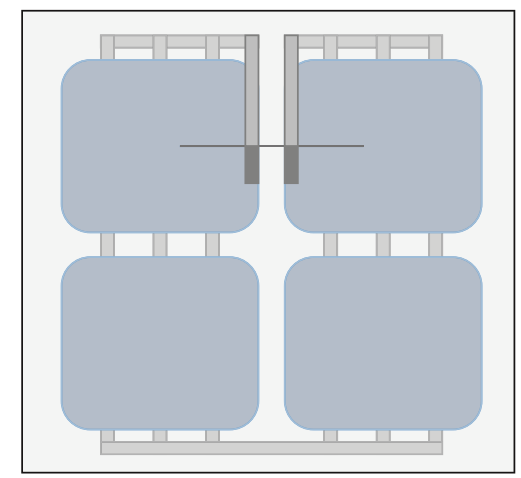

(c)

FIGURE 5: Schematic of the PV modules: (a) front side of the sample without Al, (b) front side of the sample with Al, and (c) backside of both of the samples.

metal on the power output, $I-V$ characteristics were measured as shown in Figure 7. The changes in five normalized average electrical parameters, maximum power output $P_{m}$, open circuit voltage $V_{\mathrm{OC}}$, short circuit current $I_{\mathrm{SC}}$, fill factor FF, and series resistance $R_{S}$, are plotted in Figures $7(\mathrm{a})-7(\mathrm{e})$, respectively, and summarized in Table 1 . The average $P_{m}$ of each condition decreases with increasing time. In the as-prepared cells, $P_{m}$ decreased by $86.3 \%$ compared to the initial value, whereas in the cells with a $\mathrm{Zn}$ sacrificial anode $P_{m}$ dropped by $31.1 \%$. Figure $7(\mathrm{~b})$ indicates that there were few changes in
$V_{\text {OC }}$, regardless of added sacrificial metal. However, $I_{\mathrm{SC}}$ and FF in the as-prepared samples decreased more over time than those of the samples with $\mathrm{Zn}$. Figure 7(e) reveals that $R_{S}$ in unmodified cells and $R_{S}$ in cells containing $\mathrm{Zn}$ increased by a factor of approximately 1190 and 220 compared to the initial values, respectively. The main impact of $R_{S}$ is the reduction in FF, as shown in Figure 7(d). The value of $R_{S}$ arises from the sum of resistances in solder joints, emitter and base regions, cell metallization, and cell-interconnecting bus bars [23]; its increase indicates a reduction in the power produced by the 
TABLE 2: Changes in normalized electrical parameters of PV modules with and without $\mathrm{Al}$ after $2500 \mathrm{~h}$.

\begin{tabular}{lccccc}
\hline Sample & $\mathrm{Pm}(\%)$ & $V_{\mathrm{OC}}(\%)$ & $I_{\mathrm{SC}}(\%)$ & $\mathrm{FF}(\%)$ & $R_{S}(\%)$ \\
\hline W/O Al & -28.8 & -3.5 & -6.0 & -21.5 & 165 \\
W/Al & -19.3 & -2.8 & -1.1 & -16.1 & 144 \\
\hline
\end{tabular}

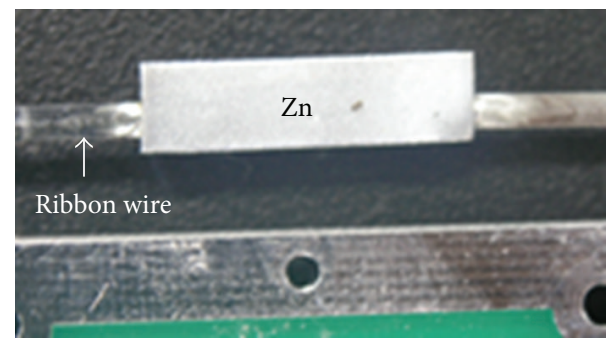

(a)

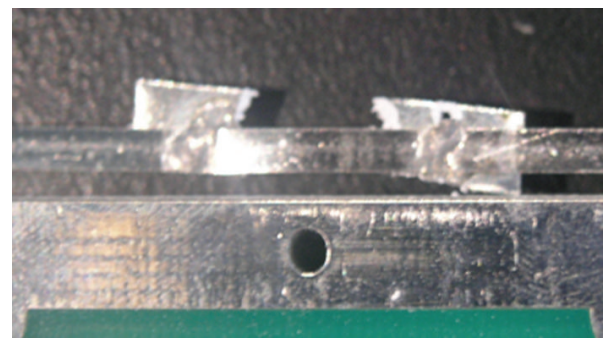

(c)

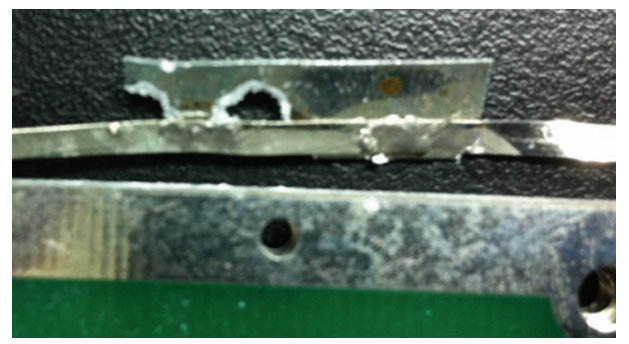

(b)

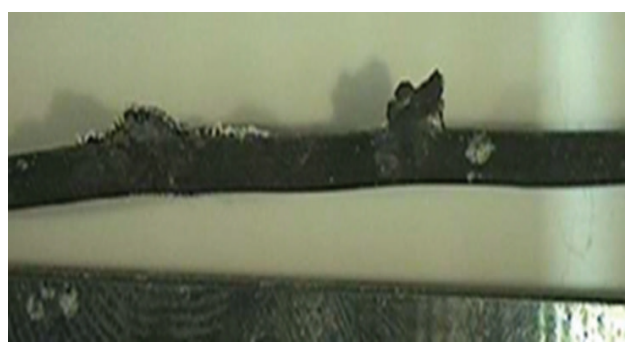

(d)

FIGURE 6: Corrosion of the sacrifice metal, Zn, with DH exposure: (a) initial, (b) $200 \mathrm{~h}$, (c) $500 \mathrm{~h}$, and (d) $1000 \mathrm{~h}$.

cell, which ultimately depreciates the performance of the PV cell. The reduction of $P_{m}$ can thus be attributed to the increase in $R_{S}$ over time, which suggests that the main reason for decrease in $P_{m}$ over the lifetime of the cell is the reduction in FF. These results confirm that the reliability of a PV module can be improved by applying sacrificial Zn to the PV cell.

\subsection{Effect of $\mathrm{Al}$ on the Electrical Parameters. Changes in} average normalized electrical parameters in PV modules with and without $\mathrm{Al}$ are plotted in Figure 8 . After $2500 \mathrm{~h}$, the $P_{m}$ of the modules with and without $\mathrm{Al}$ decreased by $19.3 \%$ and $28.8 \%$, respectively, as compared to the initial values. There were few changes in $I_{\mathrm{SC}}$ and $V_{\mathrm{OC}}$; however, the FF of modules with and without $\mathrm{Al}$ decreased by $16.1 \%$ and $21.5 \%$, respectively. $R_{S}$ of modules with and without $\mathrm{Al}$ increased by $44.3 \%$ and $64.7 \%$ compared to the initial values, respectively. These results are summarized in Table 2 . The results imply that the decrease in $P_{m}$ can be attributed to the FF drop, due to the increase in $R_{S}$.

EL images of PV modules with or without $\mathrm{Al}$ after different periods of DH exposure are shown in Figure 9. EL analysis detects cracks in cells and other areas that cannot be reached by the electricity of the cell's excitation. Darkness in the EL image indicates that the PV module has a problem generating current in that location. These results can be caused by solar cell degradation, electrode degradation, and corrosion of soldered interconnections [24]. Figure 9 shows that the PV module without $\mathrm{Al}$ showed more drastic deterioration than the sample with Al. This implies that the presence of $\mathrm{Al}$ affected the degradation of the PV module. It may be assumed that $\mathrm{Al}$ plays a role as a sacrificial anode (SA), and therefore it is corroded instead of the $\mathrm{Sn}$ and $\mathrm{Pb}$ metals in the solder.

To verify the cause of the drastic degradation shown in the EL images of PV modules with and without $\mathrm{Al}, I-V$ mapping of the modules was performed as shown in Figure 10. The image depicts the $R_{S}$ mapping of PV modules with and without Al after $2500 \mathrm{~h}$. Blue corresponds to high resistance, while green color indicates relatively low resistance in Figure 10(a). The image reveals that degradation of the PV modules occurs at the edges of the cells. Figure 10(a) shows that the sample with $\mathrm{Al}$ (indicated as "with SA") possessed a relatively low $R_{S}$ compared to the module without Al. $I$ $V$ curves of areas 1, 2, and 3, marked in Figure 10(a), were measured as shown in Figure 10(b). The size of each area was $4.85 \mathrm{~cm}^{2}$. Figure 10(a) shows that the $R_{S}$ in area 1 was higher than that in area 2 . This result is confirmed by the $I-V$ curve shown in Figure 10(b). Figure 10(b) also indicates that the $V_{\mathrm{OC}}$ of areas 1,2 , and 3 are equivalent; however, the $R_{S}$ is dependent on the area's location on the cell. From these results, it is expected that the corrosion of PV modules may be mitigated using sacrificial metal, which alleviates degradation at the edges of the cell caused by the ingress of water vapor. 


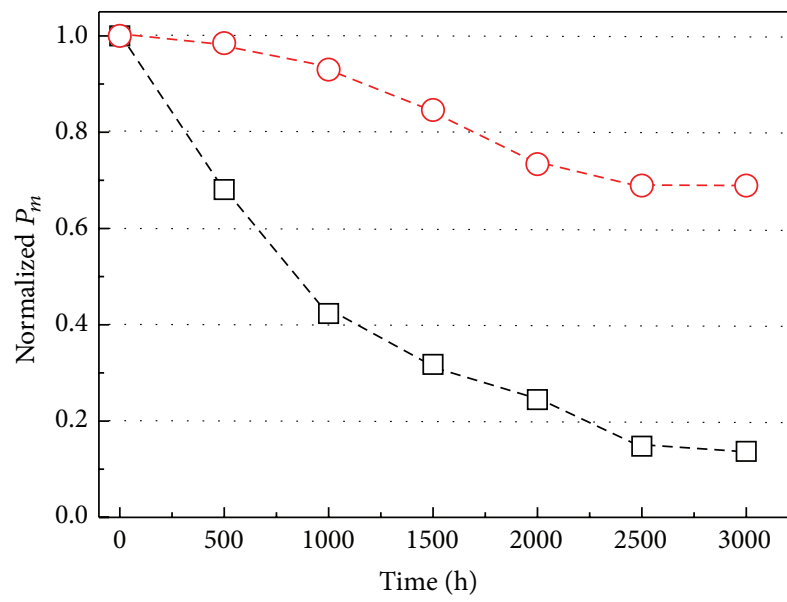

(a)

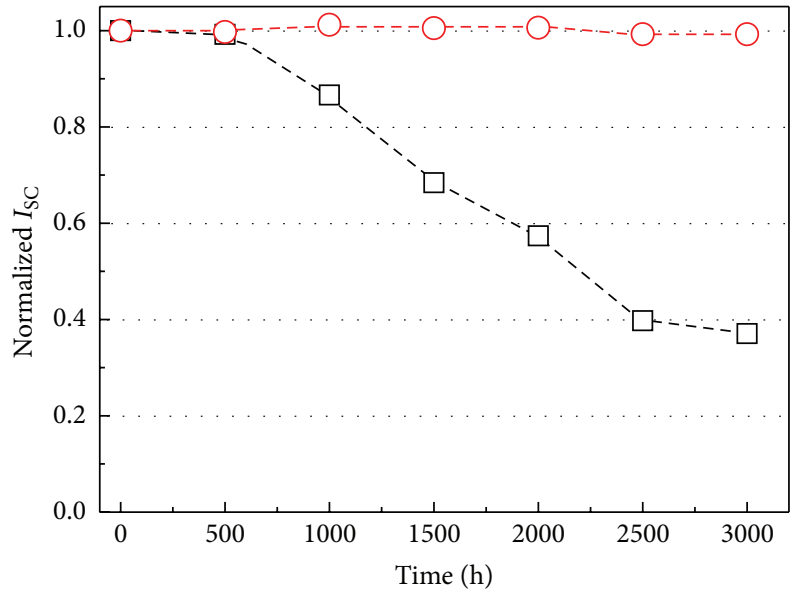

(c)

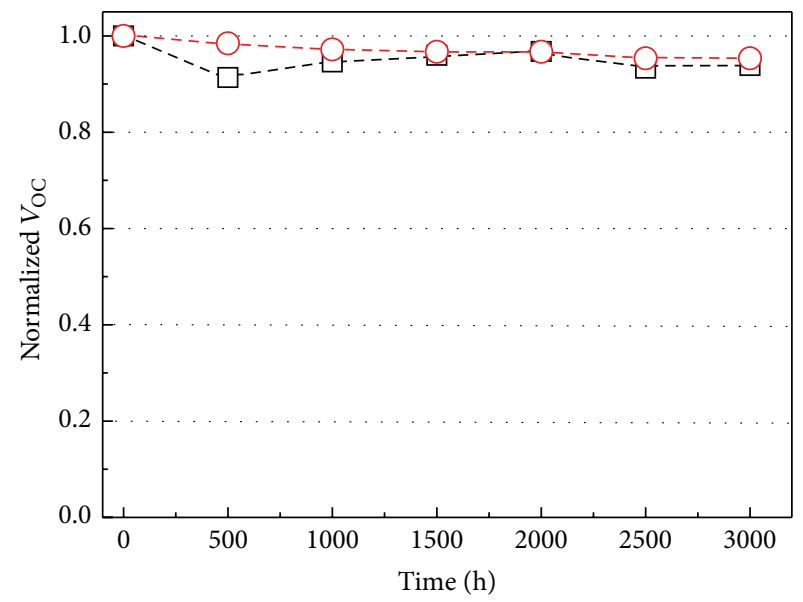

(b)

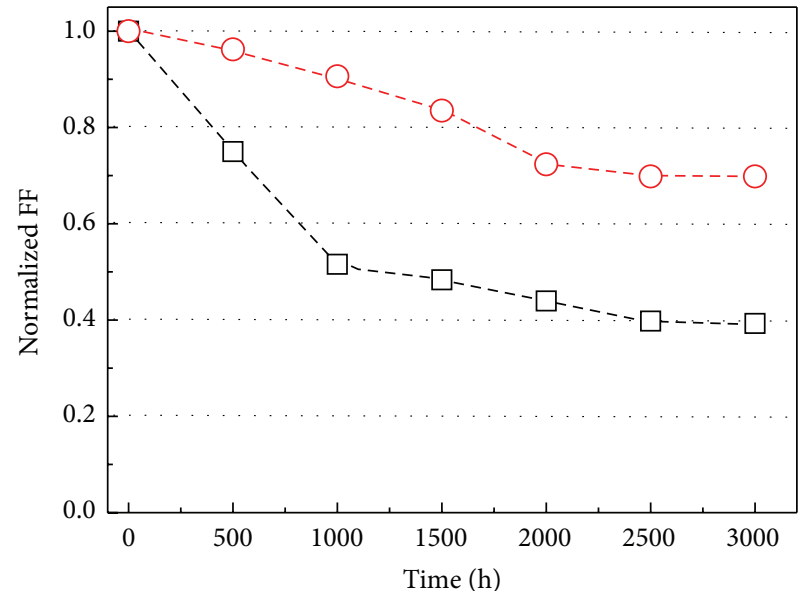

(d)

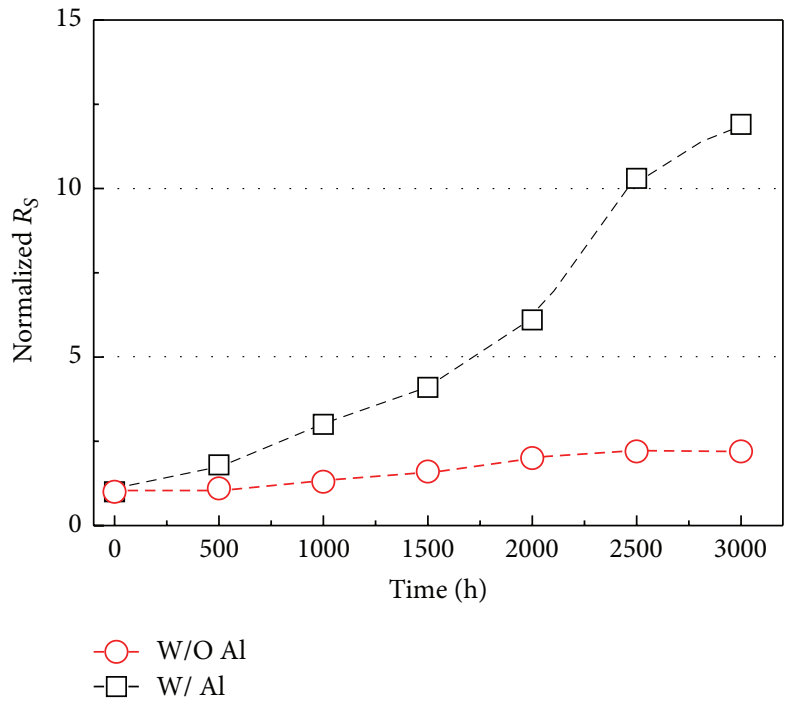

(e)

FIGURE 7: Change in average normalized electrical parameters of an unlaminated PV cell: (a) average maximum power $\left(P_{m}\right)$, (b) open-circuit voltage $\left(V_{\mathrm{OC}}\right)$, (c) short-circuit current $\left(I_{\mathrm{SC}}\right)$, (d) fill factor $(\mathrm{FF})$, and (e) series resistance $\left(R_{\mathrm{S}}\right)$. 


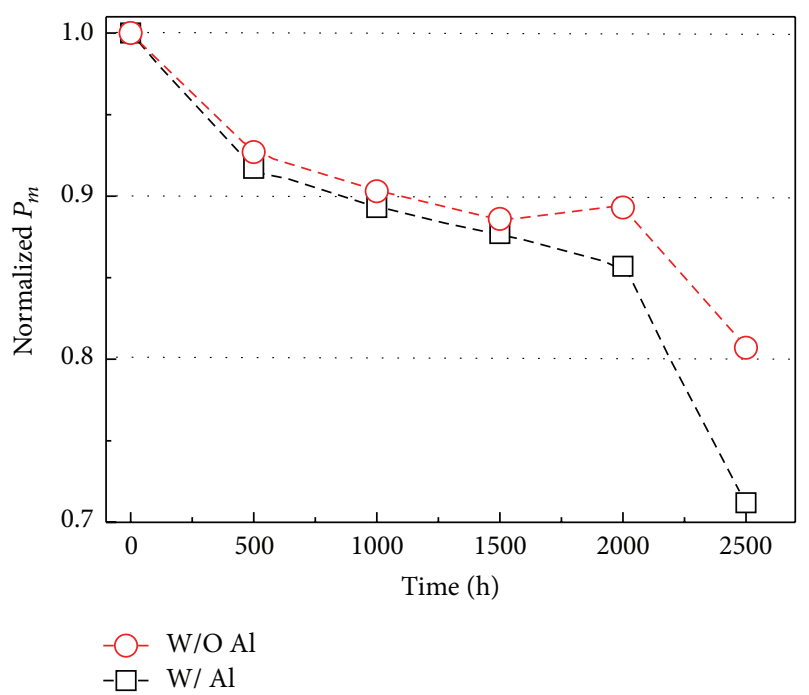

(a)

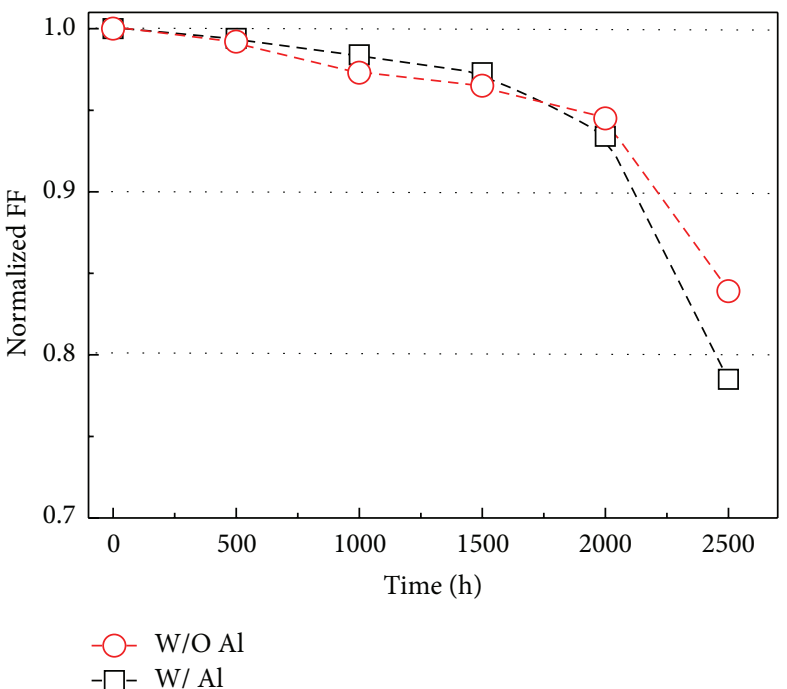

(b)

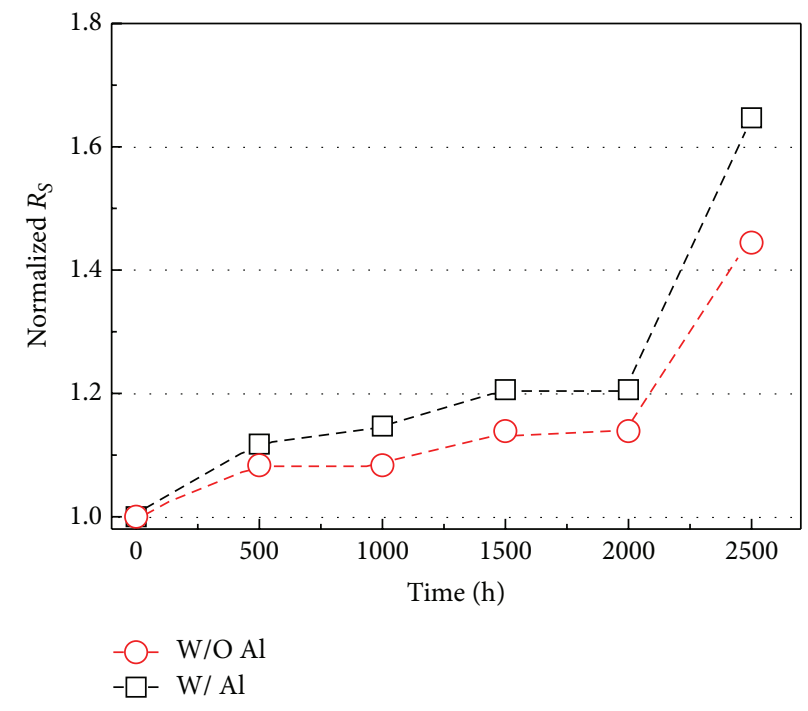

(c)

FIGURE 8: Change in average normalized electrical parameters of laminated PV modules: (a) maximum power $\left(P_{m}\right)$, (b) fill factor (FF), and (c) series resistance $\left(R_{S}\right)$.

\section{Conclusions}

The objective of this study was to investigate the effect of sacrificial metal on the reliability of PV modules under $\mathrm{DH}$ conditions. The main reason for degradation of PV cells was identified to be galvanic corrosion through the analysis of degradation in PV modules aged for 25 years. Based on this degradation mechanism of galvanic corrosion, a mitigation method involving the use of sacrificial metal was developed. $\mathrm{Zn}$ and $\mathrm{Al}$ were found to be more susceptible to corrosion in water than $\mathrm{Sn}$ and $\mathrm{Pb}$ in the solder. Either $\mathrm{Zn}$ or $\mathrm{Al}$ was attached to a PV cell's $\mathrm{Cu}$ bus-bar, plated with $62 \mathrm{Sn} 36 \mathrm{~Pb} 2 \mathrm{Ag}$ solder. Electrical characterization test results after DH exposure show that the main reason for $P_{m}$ decrease in aged PV cells was the drop in FF. This drop was attributed to the increase of $R_{S}$. The $R_{S}$ in PV cells without any added metal showed a greater increase than the $R_{S}$ of PV cells with added $\mathrm{Zn}$ or $\mathrm{Al}$. Increases in $R_{\mathrm{S}}$ are associated with solder corrosion. EL images also show that a PV module with sacrificial metal was less degraded than a sample without sacrificial metal. Lastly, the most degradation occurs at the edges of the cell, according to the $R_{S}$ mapping images, which could be alleviated using the sacrificial metal. We conclude that sacrificial metal may improve the long-term reliability of $\mathrm{PV}$ modules under $\mathrm{DH}$ conditions.

\section{Conflict of Interests}

The authors declare that there is no conflict of interests regarding the publication of this paper. 


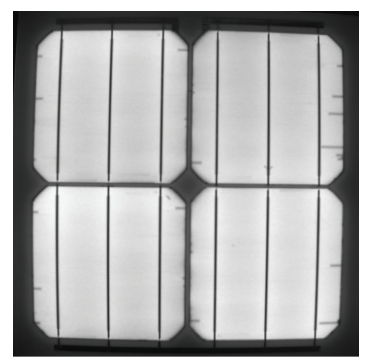

(a)

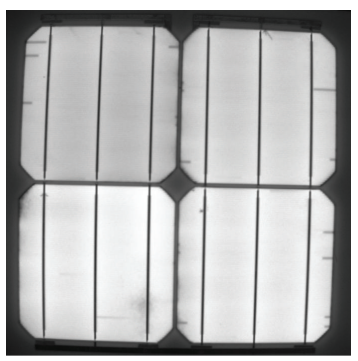

(e)

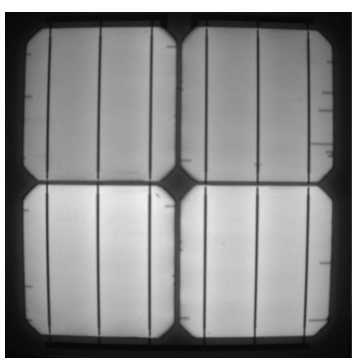

(b)

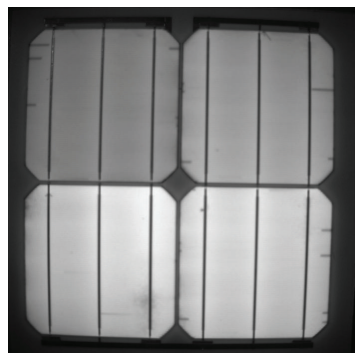

(f)

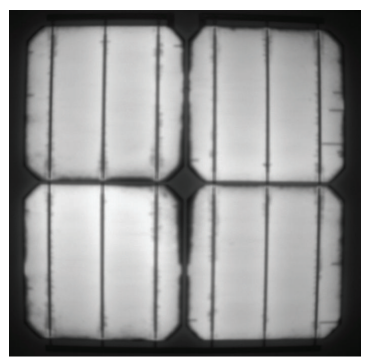

(c)

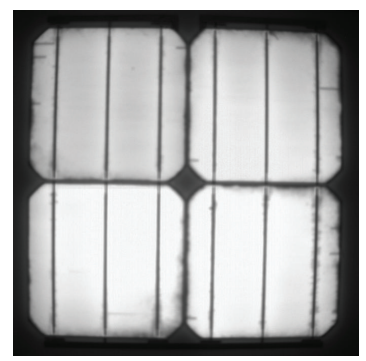

(g)

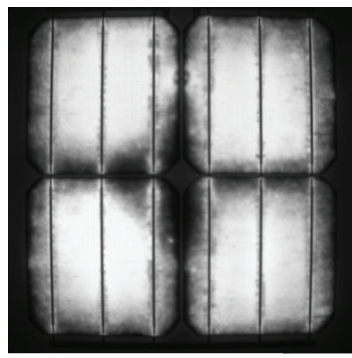

(d)

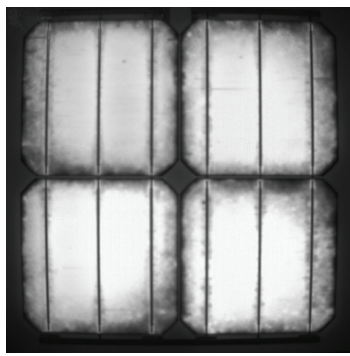

(h)

FIGURE 9: EL images of PV modules: the sample without Al after (a) $0 \mathrm{~h}$, (b) $1000 \mathrm{~h}$, (c) $2000 \mathrm{~h}$, and (d) $2500 \mathrm{~h}$ of DH exposure and the sample with $\mathrm{Al}$ after (e) $0 \mathrm{~h},(\mathrm{f}) 1000 \mathrm{~h},(\mathrm{~g}) 2000 \mathrm{~h}$, and (h) $2500 \mathrm{~h}$ of DH exposure.

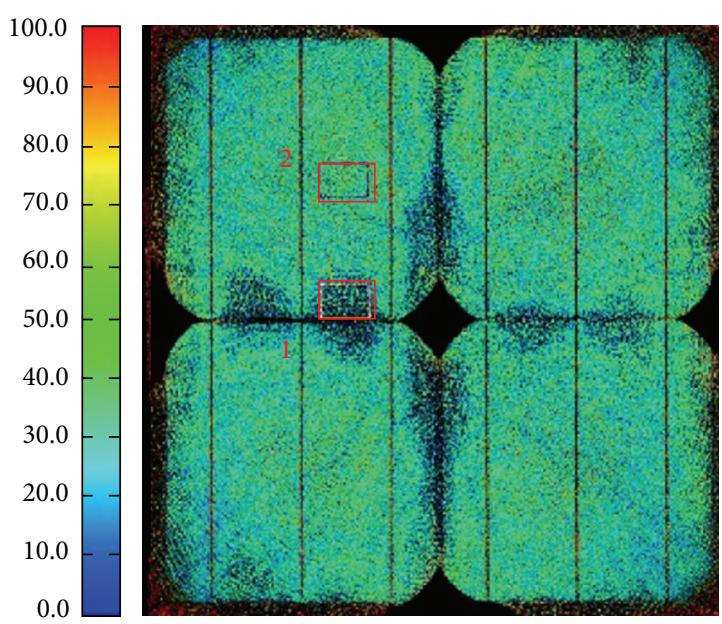

Without $\mathrm{Al}$

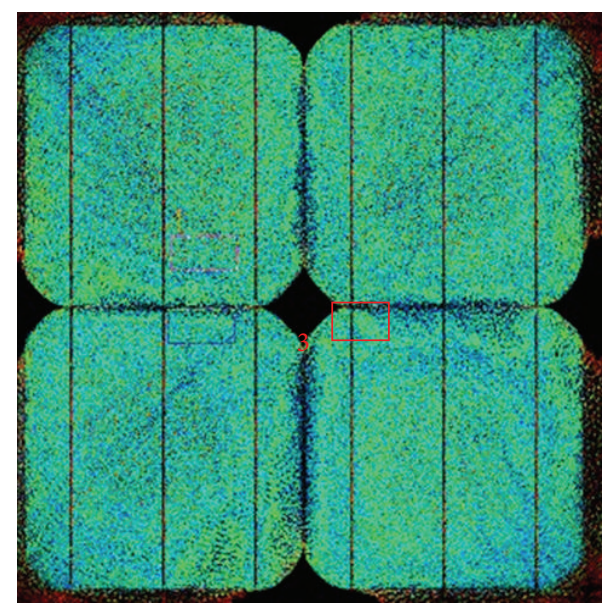

With $\mathrm{Al}$

(a)

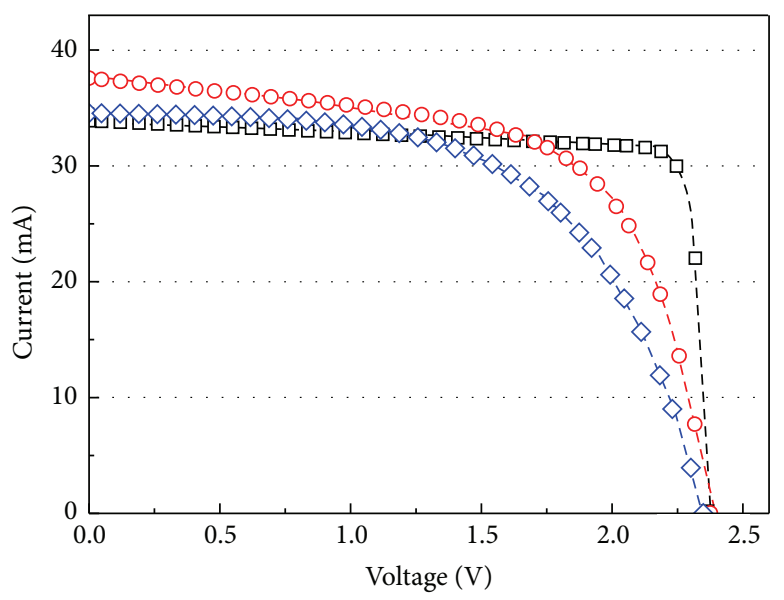

$-\diamond-(1)$ W/O Al_edge

- - (2) W/O Al_center

- - - (3) W/ Al_edge

(b)

FIGURE 10: $I$ - $V$ mapping analysis of PV modules: (a) $R_{S}$ mapping images without and with $\mathrm{Al}$ sacrificial anodes (SA) and (b) $I-V$ curves of each marked position in the cell after $2500 \mathrm{~h}$ of $\mathrm{DH}$ exposure. 


\section{Acknowledgment}

This work was supported by the New \& Renewable Energy of the Korea Institute of Energy Technology Evaluation and Planning (KETEP) Grant funded by the Ministry Of Trade, Industry \& Energy (MOTIE) (no. 2012T100100605).

\section{References}

[1] IEA-PVPS, PVPS report a snapshot of global PV, 2014.

[2] W. Short, D. J. Packey, and T. Holt, A Manual for the Economic Evaluation of Energy Efficiency and Renewable Energy Technologies, University Press of the Pacific, 2005.

[3] M. A. Quintana, D. L. King, T. J. McMahon, and C. R. Osterwald, "Commonly observed degradation in field-aged photovoltaic modules," in Proceedings of the 29th IEEE Photovoltaic Specialists Conference, pp. 1436-1439, May 2002.

[4] A. M. Reis, N. T. Coleman, M. W. Marshall, P. A. Lehman, and C. E. Chamberlin, "Comparison of PV module performance before and after 11-years of field exposure," in Proceedings of the IEEE Photovoltaic Specialists Conference, pp. 1432-1435, IEEE, 2002.

[5] A. Parretta, M. Bombace, G. Graditi, and R. Schioppo, "Optical degradation of long-term, field-aged c-Si photovoltaic modules," Solar Energy Materials and Solar Cells, vol. 86, no. 3, pp. 349-364, 2005.

[6] A. J. Carr and T. L. Pryor, "A comparison of the performance of different PV module types in temperate climates," Solar Energy, vol. 76, no. 1-3, pp. 285-294, 2004.

[7] M. A. Munoz, M. C. Alonso-García, N. Vela, and F. Chenlo, "Early degradation of silicon PV modules and guaranty conditions," Solar Energy, vol. 85, no. 9, pp. 2264-2274, 2011.

[8] S. Mau, T. Krametz, W. Jahna, and H. Fechner, "Quality testing for PV-modules according to standards and performance control for supporting manufacturing," in Proceedings of the 19th European Photovoltaic Solar Energy Conference and Exhibition (EUPVSEC '04), Paris, France.

[9] P. Peng, A. Hu, W. Zheng et al., "Microscopy study of snail trail phenomenon on photovoltaic modules," RSC Advances, vol. 2, no. 30, pp. 11359-11365, 2012.

[10] N. G. Dhere and N. R. Raravikar, "Adhesional shear strength and surface analysis of a PV module deployed in harsh coastal climate," Solar Energy Materials and Solar Cells, vol. 67, no. 1-4, pp. 363-367, 2001.

[11] X. Han, Y. Wang, L. Zhu, H. Xiang, and H. Zhang, "Mechanism study of the electrical performance change of silicon concentrator solar cells immersed in de-ionized water," Energy Conversion and Management, vol. 53, no. 1, pp. 1-10, 2012.

[12] J.-S. Jeong, N. Park, and C. Han, "Field failure mechanism study of solder interconnection for crystalline silicon photovoltaic module," Microelectronics Reliability, vol. 52, no. 9-10, pp. 23262330, 2012.

[13] D. Polverini, M. Field, E. Dunlop, and W. Zaaiman, "Polycrystalline silicon PV modules performance and degradation over 20 years," Progress in Photovoltaics: Research and Applications, vol. 21, no. 5, pp. 1004-1015, 2013.

[14] R. Laronde, A. Charki, and D. Bigaud, "Fetime estimation of a photovoltaic module subjected to corrosion due to damp heat testing," Journal of Solar Energy Engineering, Transactions of the ASME, vol. 135, no. 2, Article ID 021011, 8 pages, 2013.
[15] C. Peike, S. Hoffmann, P. Hülsmann et al., "Origin of dampheat induced cell degradation," Solar Energy Materials and Solar Cells, vol. 116, pp. 49-54, 2013.

[16] C. Dechthummarong, B. Wiengmoon, D. Chenvidhya, C. Jivacate, and K. Kirtikara, "Physical deterioration of encapsulation and electrical insulation properties of PV modules after longterm operation in Thailand," Solar Energy Materials and Solar Cells, vol. 94, pp. 1437-1440, 2010.

[17] M. Köntges, V. Jung, and U. Eitner, "Requirements on metallization schemes on solar cells with focus on photovoltaic modules," in Proceedings of the 2nd Workshop on Metallization of Crystalline Silicon Solar Cells, 2010.

[18] R. Khatri, S. Agarwal, I. Saha, S. K. Singh, and B. Kumar, "Study on long term reliability of photo-voltaic modules and analysis of power degradation using accelerated aging tests and electroluminescence technique," Energy Procedia, vol. 8, pp. 396-401, 2011.

[19] E. E. Stansbury and R. A. Buchanan, Fundamentals of Electrochemical Corrosion, ASM International, 2000.

[20] S. Reiber, "Galvanic stimulation of corrosion on lead-tin soldersweated joints," Journal American Water Works Association, vol. 83, pp. 83-91, 1991.

[21] N. C. Park, J. S. Jeong, B. J. Kang, and D. H. Kim, "The effect of encapsulant discoloration and delamination on the electrical characteristics of photovoltaic module," Microelectronics Reliability, vol. 53, no. 9-11, pp. 1818-1822, 2013.

[22] S. Reiber, "Galvanic stimulation of corrosion on lead-tin soldersweated joints," Journal/American Water Works Association, vol. 83, no. 7, pp. 83-91, 1991.

[23] S. R. Wenham, M. A. Green, and M. Watt, Applied Photovotlaics, Centre for Photovoltaic Devices and Systems, University of New South Wales, Sydney, Australia, 1995.

[24] T. H. Kim, N. C. Park, and D. H. Kim, "The effect of moisture on the degradation mechanism of multi-crystalline silicon photovoltaic module," Microelectronics Reliability, vol. 53, no. 911, pp. 1823-1827, 2013. 

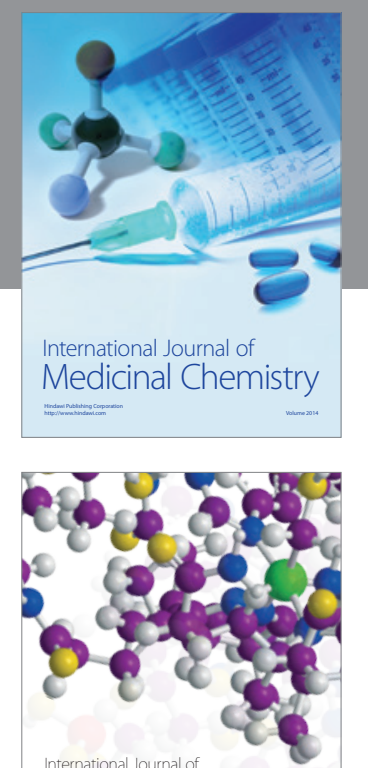

\section{Carbohydrate} Chemistry

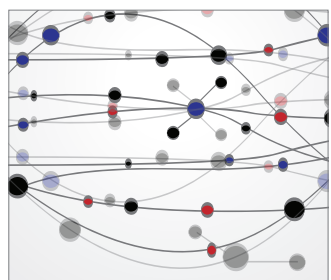

The Scientific World Journal
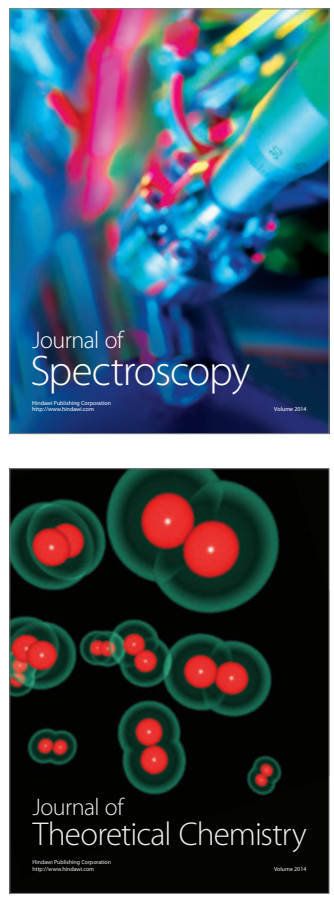
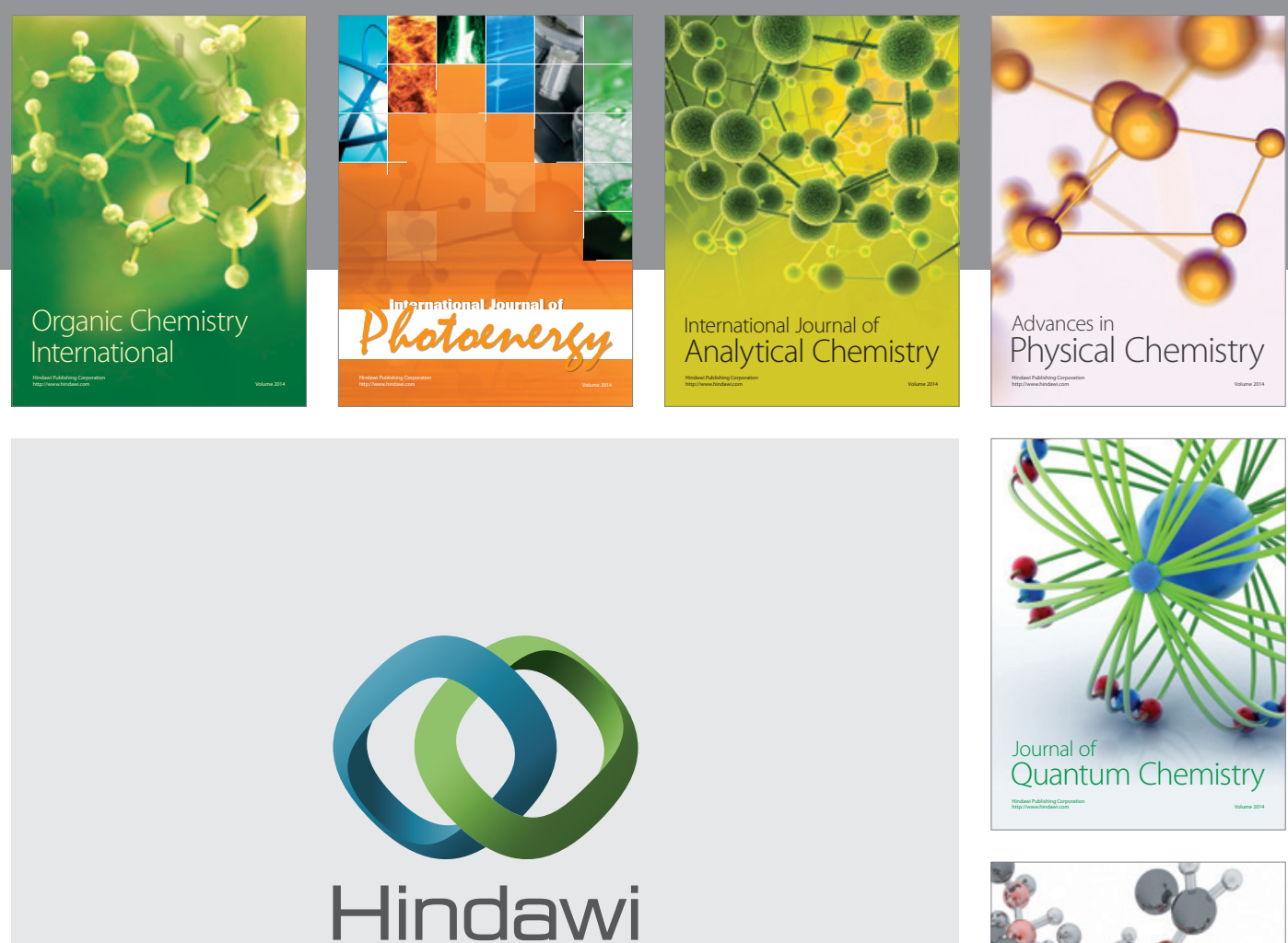

Submit your manuscripts at

http://www.hindawi.com

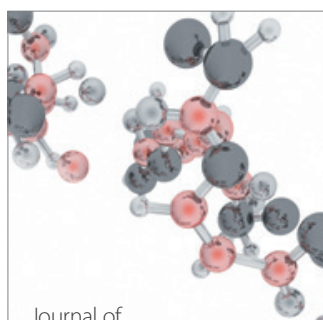

Analytical Methods

in Chemistry

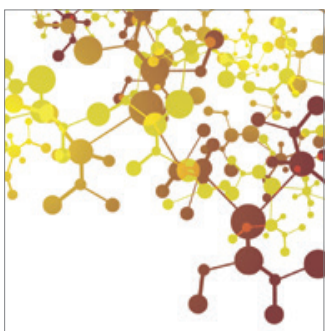

Journal of

Applied Chemistry

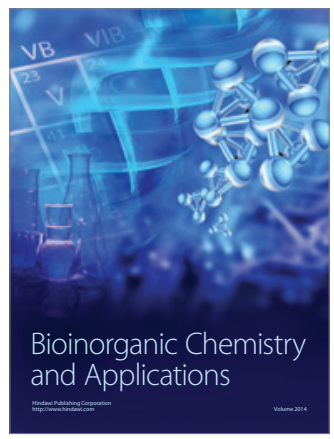

Inorganic Chemistry
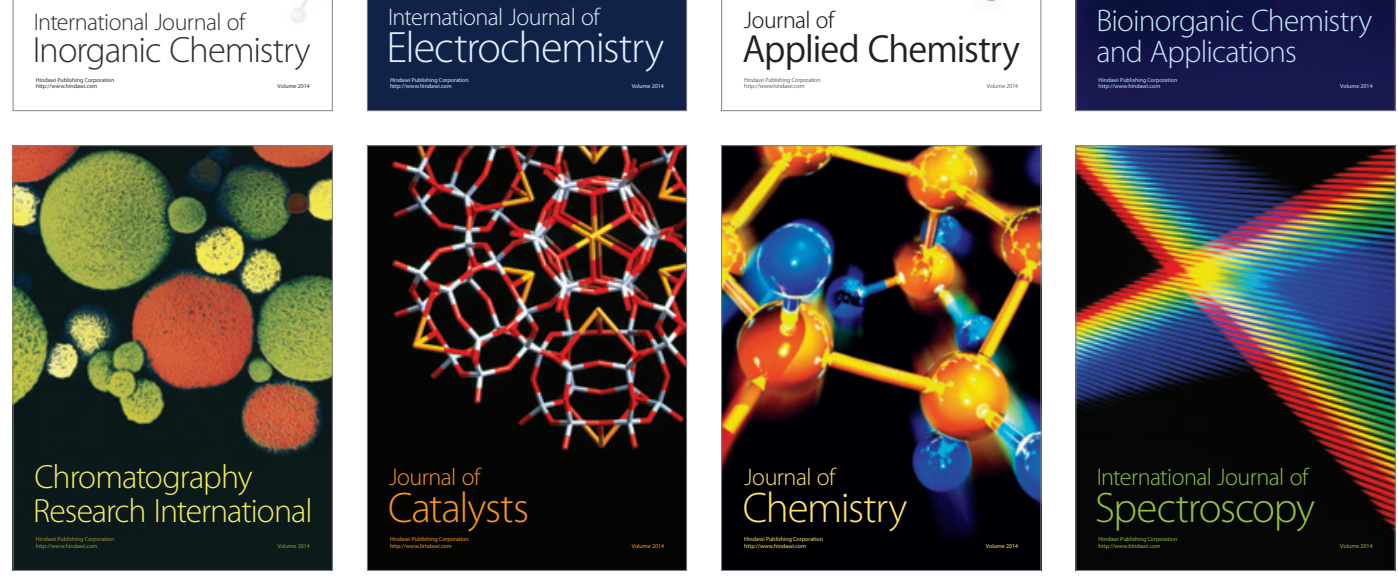